\title{
CharaCterization OF MATERIALS USED IN 3D-PRinTing TECHNOLOGY WITH DIFFERENT ANALYSIS TECHNIQUES
}

\author{
$\mathrm{M}^{\mathrm{a}}$ Angeles Castro-Sastre, Ana Isabel Fernández-Abia, \\ Pablo Rodríguez-González, Susana Martínez-Pellitero \& Joaquín Barreiro
}
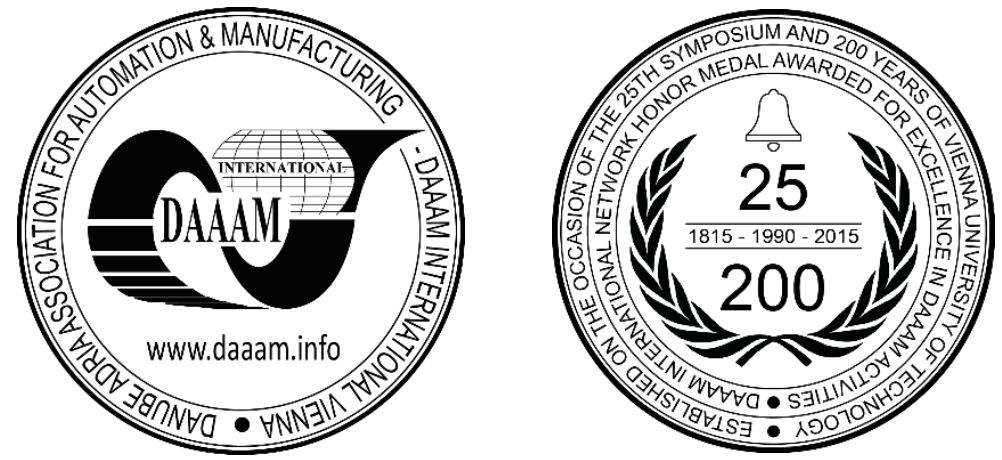

This Publication has to be referred as: Castro-Sastre, A[ngeles]; Fernández-Abia, A[na] I[sabel]; Rodriguez-Gonzalez, P[ablo]; Martínez-Pellitero, S[usana] \& Barreiro, J[oaquin] (2018). Characterization of Materials Used in 3D-Printing Technology with Different Analysis Techniques, Proceedings of the 29th DAAAM International Symposium, pp.09470954, B. Katalinic (Ed.), Published by DAAAM International, ISBN 978-3-902734-20-4, ISSN 1726-9679, Vienna, Austria

DOI: $10.2507 / 29$ th.daaam.proceedings.136

\begin{abstract}
3D inkjet printing is mainly a powder-based method where layers of solid particles are bounded together by means of a printed liquid material to generate a 3D model. In this process, it is necessary to control different parameters that can significantly affect the quality of 3D printed parts, such as: chemical composition, structural elucidation, particles morphology, among others. For this reason, the purpose of this research was to develop a study of the chemical and physical properties of the two involved materials: the powder, hemihydrate calcium sulphate $80-90 \%$ of purity, and the binder, 2-pyrrolidone $1 \%$ of purity. Both materials were studied with different techniques to characterize different parameters. Raman and FT-IR spectrometry and X-ray diffractometer (XRD) were used to study structural elucidation and presence to others phases of this sulphate powder; for knowing the kind of impurities and morphological aspect; we used scanning electron microscope (SEM), equipped with an energy-dispersive X-ray detecting system (ED-XRS), and inductive coupling plasma (ICP) with optical emission spectrophotometer (OES). The results showed the real composition of solid powder and liquid binder. The images of secondary electrons obtained showed the presence of alpha and beta phase of called hemihydrated sulphate. The presence of other phases of sulphate, such as dihydrate and anhydrous, was also detected. This information is important to know the properties of the manufactured part.
\end{abstract}

Keywords: 3D inkjet printing; material characterization; additive manufacturing; powder bed printing; calcium sulphate

\section{Introduction}

Additive Manufacturing (AM) has emerged as a technology for manufacturing objects with complex geometries from three-dimensional (3D) model data. New AM methods, materials and applications are being developed continuously. A review of materials, methods, applications and challenges can be found in [1]. One of the most important AM methods for ceramic components is three-dimensional printing (3DP). This method is a powder-based process where fine powder particles are bound together with a liquid binder to create a 3D part. The powder particles are spread and packed on a platform and a liquid binder is deposited onto the powder layer, using a printer head, to join the particles. 
The process is repeated by spreading a new layer of powder on top of the previous layer that results in the creation of a 3D structure [2] [3]. 3DP technology can use a wide variety of materials (powder and binder) for different applications. In order to build ceramic components, the most used powders are aluminium oxide $\left(\mathrm{Al}_{2} \mathrm{O}_{3}\right)$, zirconium oxide $\left(\mathrm{ZrO}_{2}\right)$, silicium oxide $\left(\mathrm{SiO}_{2}\right)$, calcium hemihydrate $\left(\mathrm{CaSO}_{4}{ }_{1 / 2} \mathrm{H}_{2} \mathrm{O}\right)$ and calcium hydroxyapatite $\left.\left(\mathrm{Ca}_{5}\left(\mathrm{PO}_{4}\right)_{3} \mathrm{H}\right)\right)$. On the other hand, different types of binder have also been used: 2-Pyrrolidone $\left(\mathrm{C}_{4} \mathrm{H}_{7} \mathrm{NO}\right)$, $\alpha$-n-butyl cyanoacrylate (NBCA) $\left(\mathrm{C}_{8} \mathrm{H}_{11} \mathrm{NO}_{2}\right)$, Polyvinyl Alcohol (PVA) $\left(\left(\mathrm{C}_{2} \mathrm{H}_{4} \mathrm{O}\right)_{\mathrm{x}}\right)$ and $10 \mathrm{wt} \%$ phosphoric acid $\left(\mathrm{H}_{3} \mathrm{PO}_{4}\right)$ among others [4].

Calcium hemihydrate, also called Plaster of Paris (Bassanite), was the first material used for 3D Printing technology. This material has been widely used in many areas such as precision instrument moulds, ceramics, industrial arts and architecture, due to its workability [5]. However, applications of this material using 3DP technology are focused in medical and dental applications. There are numerous works that study the optimization of the process for bone scaffolds fabrication [6] [7] and to make dental models [8]. The advantage of using Calcium hemihydrate for medical applications is because it is harmless to humans and has the ability to directly print porous scaffolds with designed shape, controlled chemistry and interconnected porosity [9]. For these applications and for any other, it is very important to know the chemical and physical properties of the material. The material for 3DP technology is supplied as powder, and its characteristics such as size, shape and distribution of particle, chemical composition, physical properties and microstructure will significantly influence the resulting structure and, therefore, affect the properties of the printed part. All these characteristics are related to the method of obtaining the material.

Calcium hemihydrate is produced commercially by partial dehydration of gypsum $\left(\mathrm{CaSO}_{4} \cdot 2 \mathrm{H}_{2} \mathrm{O}\right)$. This process of dehydration consists in removing $3 / 4$ of the combined water from the gypsum, using sometimes small amounts of chemical additives. Depending on the production method that is used, wet (e.g. autoclaving) or dry (e.g. calcining), the hemihydrate is into one of two phases, $\alpha$ or $\beta$, respectively. Several authors have different opinions about the physical differences about the two phases of the hemihydrate [10]. On the other hand, use of chemical additives affects the chemical and physical properties of calcium hemihydrate (morphology and growth of crystals). These properties may change depending on the quantity, form and stage of the process in which the additives are added. Also, the nature of the additives (organic or inorganic) modifies the calcium hemihydrate properties. Therefore, we can conclude that the calcium hemihydrate morphology depends on the formation conditions and the content of chemical additives.

To characterize the material, the most used techniques, selected by their usefulness, are generally SEM-EDX, Raman Spectroscopy, X-Ray Diffraction (XDR) or Dumas Analysis [11] [12] [13]. The present work studies the real chemical composition and physical properties (microstructure and morphology) of raw materials, using the techniques advised on the bibliography and others complementary techniques (ICP-OES; FTIR), in order to know the properties of raw materials, with the aim of finding different applications for this material using 3DP technology.

\section{Experimental Procedure}

In this study a commercial plaster based powder $\mathrm{CaSO}_{4} .1 / 2 \mathrm{H}_{2} \mathrm{O}$ (VisiJet PXL Core) with a purity of $80-90 \%$ with an appropriate water based binder solution of 2-Pyrrolidone $\mathrm{C}_{4} \mathrm{H}_{7} \mathrm{NO}$ (purity of 0-1\%) (VisiJet PXL Colors Clear) were used as raw materials. Both materials are used in a 3DP machine Project 660Pro (3DSystem, USA) and have the properties showed in Table 1 according to the manufacturer's safety data sheet.

\begin{tabular}{lcc}
\hline & Binder & Plaster based powder \\
\hline $\mathrm{pH}\left(20^{\circ} \mathrm{C}\right)$ & 9,8 & - \\
\hline Boiling/Melting point $\left({ }^{\circ} \mathrm{C}\right)$ & 100 & 1450 \\
\hline Density $\left(\mathrm{g} / \mathrm{cm}^{3)}\right.$ & 1 & $2,6-2,7$ \\
\hline
\end{tabular}

Table 1. Binder and powder properties according to the manufacturer's safety data sheet

The morphological shape of the powder particles and their chemical composition were assessed using electron microscope analysis. A JEOL scanning electron microscope (Model JSM-6100) equipped with energy dispersive spectroscopy (EDS) (LINK) operated under recommended conditions (20kV acceleration voltage and 5nA probe current). Carbon tape was used to fix the specimens on the sample holder to discharge the negative charge in the microscope. Subsequently, backscattered electron images were obtained and the spectra of energy dispersive X-ray microanalysis were obtained.

In order to know the presence of impurities on the raw materials, we used inductive coupling plasma (ICP) with optical emission spectrophotometer (OES) (ICP-OES). The model was Perkin Elmer Optima 2000DV. To analyze the powder, $0.5 \mathrm{~g}$ of the gypsum sample was resuspended in $10 \mathrm{ml}$ of $63 \%$ nitric acid. Appropriate dilutions were made for the analysis, adding $5 \mathrm{ppm}$ of Sc as indicated by internal standard, to perform the calibration line. The binder did not need to be diluted because its composition is mainly water. 
The structure analysis was assessed by a PhilipsPW1830 (high voltage generator) powder X-ray diffractometer (XRD) (Philips, Almelo, The Netherlands) with a Philips PW1710/00 (diffractometer controller), working in Bragg-Brentano diffraction geometry. The current and voltage used were $30 \mathrm{~mA}$ and $40 \mathrm{kV}$, respectively. Powder samples were prepared in the form of thin layer on a zero background $\mathrm{Si}(911)$ substrate using $\mathrm{Cu}(\mathrm{K} \alpha)$ as incident radiation.

The scattered intensities were recorded in the $2 \theta$ span of $15-80^{\circ}$. The powder was also analysed using Raman spectroscopy with a portable BWTEK (i-Raman) spectrometer fitted with a CCD refrigerated detector. Raman spectrometry measurements were performed at room temperature using the $785 \mathrm{~nm}$ line of an argon-ion laser as the excitation source, model Clean Laze $(>300 \mathrm{~mW})$. The power level was set nominally at $100 \%$, but it had to be reduced on several occasions due to saturation of the detector. The experimental conditions were $10 \mathrm{~s}$ accumulation time, $1 \mathrm{~min}$ acquisition time and spectra were scanned from 200 to $2500 \mathrm{~cm}^{-1}$. With this technique we cannot study the presence of water molecules, since it only allows a working range up to $3000 \mathrm{~cm}^{-1}$ and water bands appear far away this value. Taking into account that calcium sulphate hemihydrate has different functional groups that absorb infrared light at different wavelengths to those of water, we used Fourier transform infrared (FTIR) spectroscopy (IFS66v/S, Bruker, Germany). The spectra were collected in transmittance mode in the $4000-450 \mathrm{~cm}^{-1}$ range.

Moreover the powder was analysed with the Dumas method to know the presence of carbon. This method consists in a complete combustion in an atmosphere with oxygen with reduction of the not interesting elements in a reactor. Helium is used as carrier gas at the end of the process. After passing through a water trap, $\mathrm{N}_{2}$ and $\mathrm{CO}_{2}$ are obtained and introduced in a chromatographic oven with TCD, which generates the corresponding chromatograms. The equipment used was EuroVector Elemental Analyser, EURO model EA 3000 / J1F. The sample was finely ground. Therefore, no previous pre-processing was necessary. It was weighed, in triplicate, in tin capsules. The working parameters were the following: carrier flow $(\mathrm{ml} / \mathrm{min}) 100+/-5$; carrier $(\mathrm{KPa}) 130$; purge $(\mathrm{ml} / \mathrm{min})$ 130-120; oxygen (ml) 20; sampling delay (s) 8; run time (s) 140; front furnace temp $\left({ }^{\circ} \mathrm{C}\right) 980$; GC Oven temp $\left({ }^{\circ} \mathrm{C}\right) 100$. Four patterns were used with known concentrations of $\mathrm{C}$.

\section{Results and Discussion}

The microstructure of raw powder is shown in Figure 1. From observation of the SEM images it can be concluded that the powder is a mixture of two types of particles with different morphologies: on one hand, well-formed crystals, with sharp edges and very detailed edges (Figure 1a); on the other hand, particles with more amorphous forms or undefined forms (Figure 1b).

This morphological difference is due to the method of obtaining calcium hemihydrate. The particles with sharp edges correspond to the alpha phase, obtained by wet method and the particles with undefined form correspond to the beta phase, obtained by dry method [10]. From the analysis of different images of secondary electrons, it can be deduced that most particles in the raw powder present beta phase.

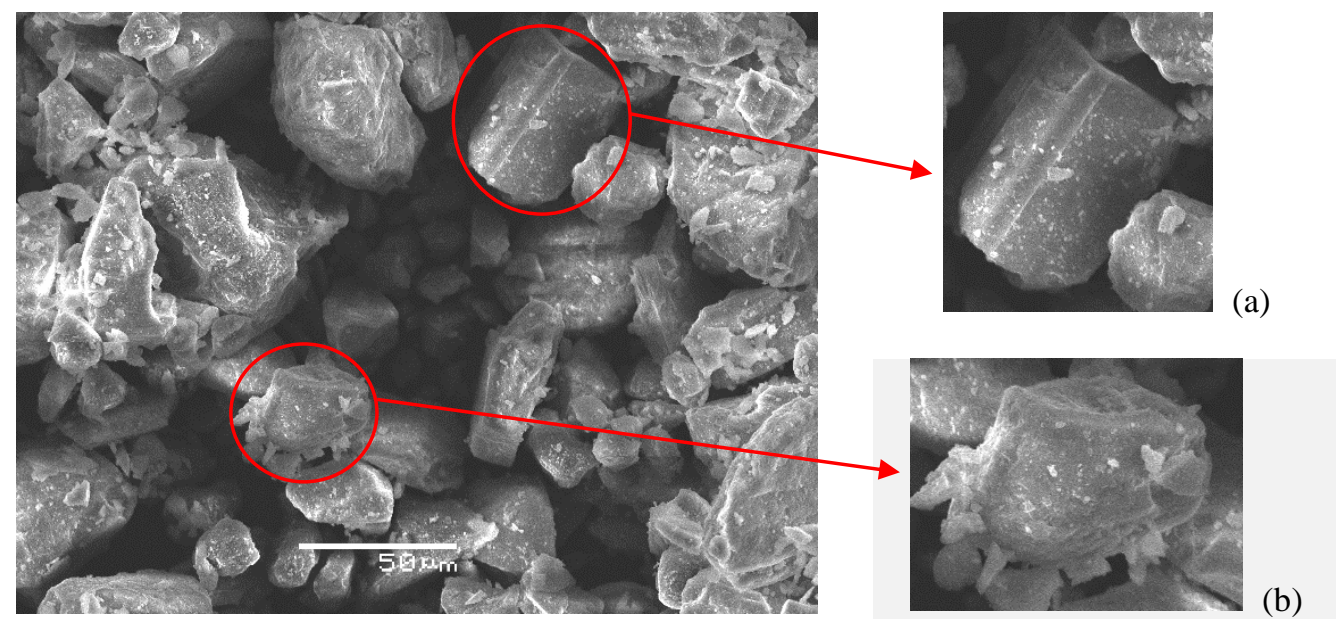

Fig. 1. SEM images of powder

The X-ray microanalysis of powder (Figure 2a), obtained at X100 magnification, shows the presence of S, Ca, O and $\mathrm{C}$, which indicates that it is calcium sulphate. The presence of carbon can be attributed to the support where the powder is deposited, since for the analysis the powder is placed on a carbon adhesive tape; however, some authors attribute it to the presence of organic components in the original powder [14]. In order to know the exact origin of the carbon, the powder was submitted to a dumas analysis. This analysis indicated that the material has a $7.19 \% \mathrm{C}$, which indicates that presence of $\mathrm{C}$ is due to some organic additive [10]. 


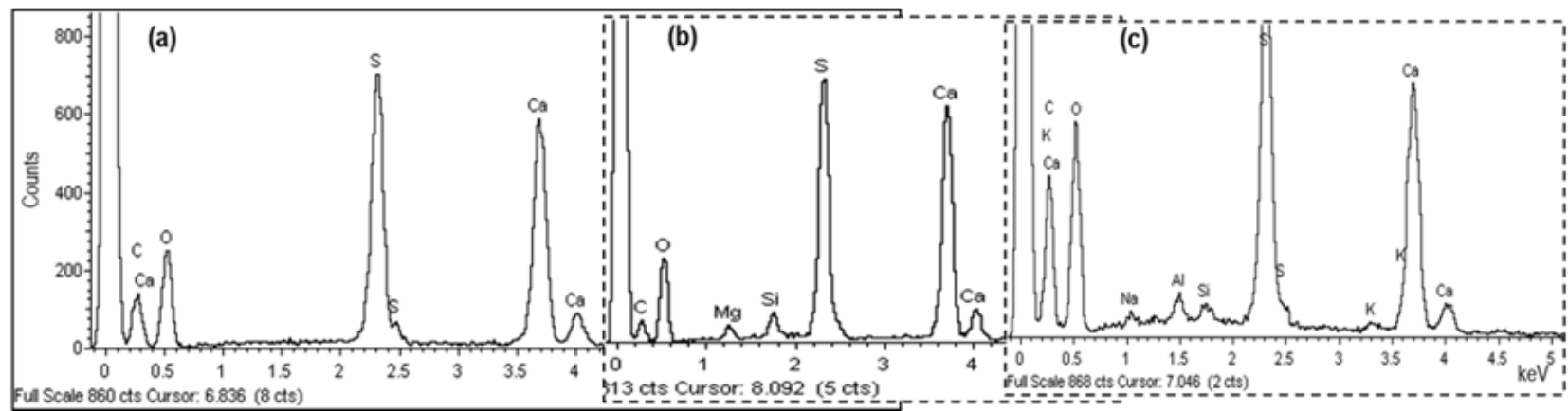

Fig. 2. SEM microanalysis of powder

Results obtained in additional areas on the particles also confirmed the presence of other elements (Figure 2b and 2c). The spectra obtained showed the presence of $\mathrm{Si}, \mathrm{K}, \mathrm{Al}, \mathrm{Mg}$ and $\mathrm{Na}$, which are on traces respect to $\mathrm{S}, \mathrm{O}$ and $\mathrm{Ca}$. Intensity of peaks relative to these elements are very low, as well as the weight percentage.

Therefore, these additional elements are considered impurities (Table 2). Except for Si, which is attributed to the original mineral from which the gypsum is obtained, the rest of elements are supplementary additives included to improve workability of the gypsum. This chemical composition of material is important because affects the properties of the 3DP printed product, such as porosity, hardness and mechanical strength. Moreover, impurities like K, Na and Mg are known to play a key role in the formation of gypsum and the dehydration process.

\begin{tabular}{|l|c|c|c|c|c|c|c|c|c|}
\hline Element & $\mathbf{O}$ & $\mathbf{S}$ & $\mathbf{C a}$ & $\mathbf{C}$ & $\mathbf{N a}$ & $\mathbf{A l}$ & $\mathbf{M g}$ & $\mathbf{S i}$ & $\mathbf{K}$ \\
\hline \%Weight & 40,31 & 13,79 & 17,89 & 28,01 & 0,28 & 0,29 & 0,95 & 1,40 & 0,67 \\
\hline
\end{tabular}

Table 2. Chemical composition of powder

Due to the importance of impurities content in the properties in the final product, a more detailed analysis was carried out. The analysis performed was ICP-OES, since it allows knowing exactly the impurities composition in the raw material. The result indicated that the predominant elements are $\mathrm{Na}$ and $\mathrm{K}$, which are added to calcium sulphate to facilitate the setting process. There is also a high content of $\mathrm{Si}$, which is present in the material used to obtain the plaster. $\mathrm{Mg}$ and $\mathrm{Al}$ are also present as trace elements.

\begin{tabular}{|c|c|c|c|c|c|}
\hline Analite & $\mathrm{Mg}(285,213)$ & $\mathrm{Na}(589,592)$ & $\mathrm{K}(766,490)$ & $\mathrm{Al}(396,153)$ & $\mathrm{Si}(251,611)$ \\
\hline $\begin{array}{c}\mathbf{C a S O} \mathbf{4} \bullet \mathbf{1 / 2 H} \mathbf{2} \mathbf{O} \\
(\mathbf{m g} / \mathbf{K g})\end{array}$ & $<4$ & 508,26 & 679,66 & $<4$ & 253,75 \\
\hline
\end{tabular}

Table 3. ICP-OES powder analysis

Once the elemental composition of the powder is known, the next step consisted in analyse the phases in the $\mathrm{CaSO}_{4} \cdot \mathrm{nH}_{2} \mathrm{O}$ system, as well as a structural study of it. For this purpose a diffraction analysis was carried out. Figure 3 displays the XRD spectra of the powder. Diffraction lines with higher intensity were found in the follow diffraction angles: $2 \theta=14.71^{\circ}, 25.65^{\circ}, 29.72^{\circ}$ and $31.8^{\circ}$, corresponding to the respective planes (200), (220), (400) and (204). The peaks with lower intensities were observed at $2 \theta=31.79^{\circ}, 42.24^{\circ}, 49.18^{\circ}, 52.92^{\circ}, 54.09^{\circ}$ and $55.11^{\circ}$, associated with the planes (422), (424), (207), (604) and (620), respectively. All these peaks are attributed to bassanite (calcium sulphate hemihydrate) [16].

Some peaks of minimum intensities, such as $2 \theta=25.33^{\circ}, 39.66^{\circ}$ and $47.58^{\circ}$ are attributed to the anhydrite. These materials are a subproduct that comes from the gypsum calcination process. According to the XDR analysis, gypsum is also present, as the peak at $11.54^{\circ}$ indicates. Also, the powder contains quartz, as indicated by the peak at $27,64^{\circ}$. In the previous XRay analysis it was detected $\mathrm{Si}$ which is an element contained in quartz. Quartz and gypsum are the species present in the mineral utilised for obtaining bassanite.

According to the pdf ICDD card 00-033-0310, 01-081-1848 consulted in the diffraction equipment database we can determine that the powder contains a higher bassanite quantity $(60,9 \%$ and 35,1\%) compared with the lesser amounts of the other sulphate phases (anhydrite and gypsum, 3,2\% and 0,7 \% respectively) and quartz (0,2\%). These quantitative analysis of present phases was confirmed using (1) proposed by Panttanayak [15].

$$
\% \text { phase }=\frac{\text { Intensity of major peak of the phase to be determined }}{\sum \text { Intensity of major peaks of all the phases }}
$$




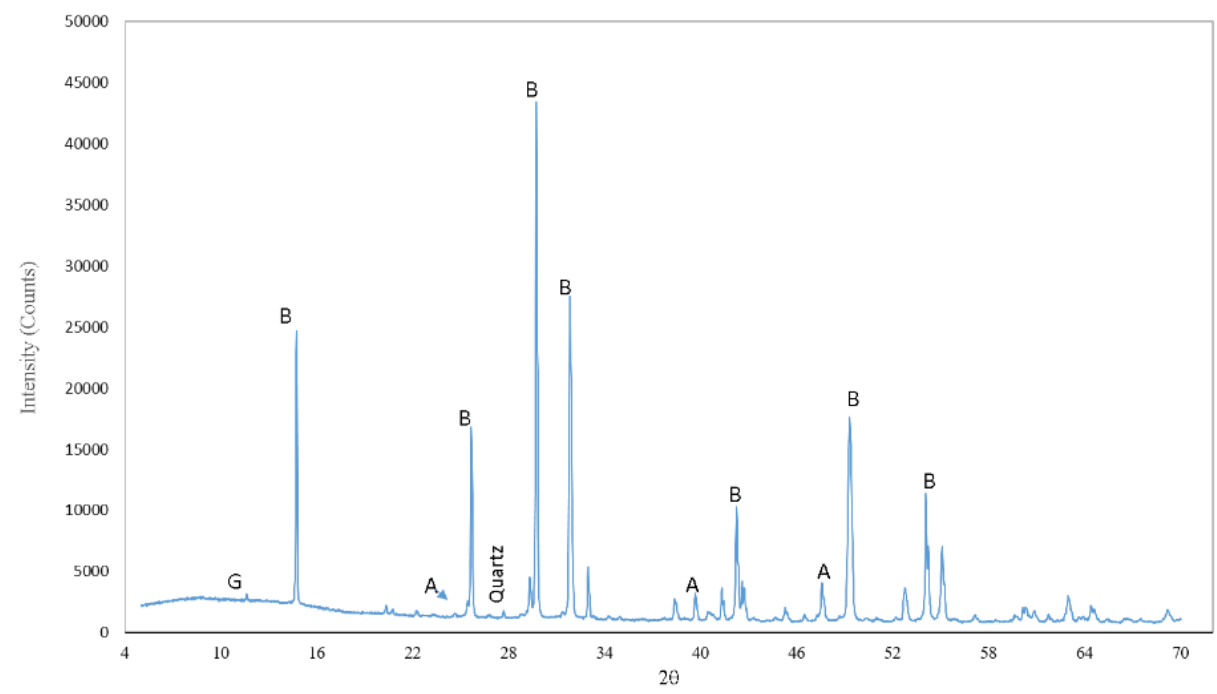

Fig. 3. XRD powder pattern. (A: Anhydrite; B: Bassanite; G: Gypsum)

According to pdf ICCD letters, bassanite has two different structures: orthorhombic and hexagonal. These two structures are indicated by the intensity relation of the $14,73^{\circ}$ and $29,72^{\circ}$ peaks. In Figure 3 it can be observed that $\mathrm{I}_{29,72}>$ $\mathrm{I}_{14,73}$, which indicates that most of the structure is orthorhombic. The presence of peaks with high intensities at $29.29^{\circ}$ and $31.82^{\circ}$ suggests the presence of hexagonal bassanite. Orthorhombic structure has been attributed to phase $\beta$ of the bassanite [16]. These results are according to SEM images (Figure 1). This information is important for the porosity study of the 3D printed part using this material [17].

In order to confirm the material characterization, the powder was analysed using Raman and FT-IR. In Raman technique it is known that the system of calcium sulphate $\left(\mathrm{CaSO}_{4} \cdot \mathrm{nH}_{2} \mathrm{O}\right)$ has a main Raman band (Table 4). In the Raman spectra (Figure 4), the area of interest was between $1000-1300 \mathrm{~cm}^{-1}$, where the most intense peaks appear relative to the different phases of $\mathrm{CaSO}_{4} \cdot \mathrm{nH}_{2} \mathrm{O}$. Both spectrum carried out on the material indicate the presence of three phases: gypsum, anhydrite and basanite at these absorption peaks $1009,16 \mathrm{~cm}^{-1} ; 1017,90 \mathrm{~cm}^{-1}$ and 1015,62 $\mathrm{cm}^{-1}$ respectively, confirming that bassanite is the main phase in the powder.

\begin{tabular}{|l|c|c|c|c|c|}
\cline { 2 - 6 } \multicolumn{1}{c|}{} & Gypsum & Bassanite & Anhydrite III & Anhydrite II & Anhydrite I \\
\hline Main Raman Band & $1008 \mathrm{~cm}^{-1}$ & $1015 \mathrm{~cm}^{-1}$ & $1025 \mathrm{~cm}^{-1}$ & $1017 \mathrm{~cm}^{-1}$ & $1017 \mathrm{~cm}^{-1}$ \\
\hline
\end{tabular}

Table 4. Summary of the different Raman band of the hydration-dehydration system of $\mathrm{CaSO}_{4} \bullet \mathrm{nH}_{2} \mathrm{O}$

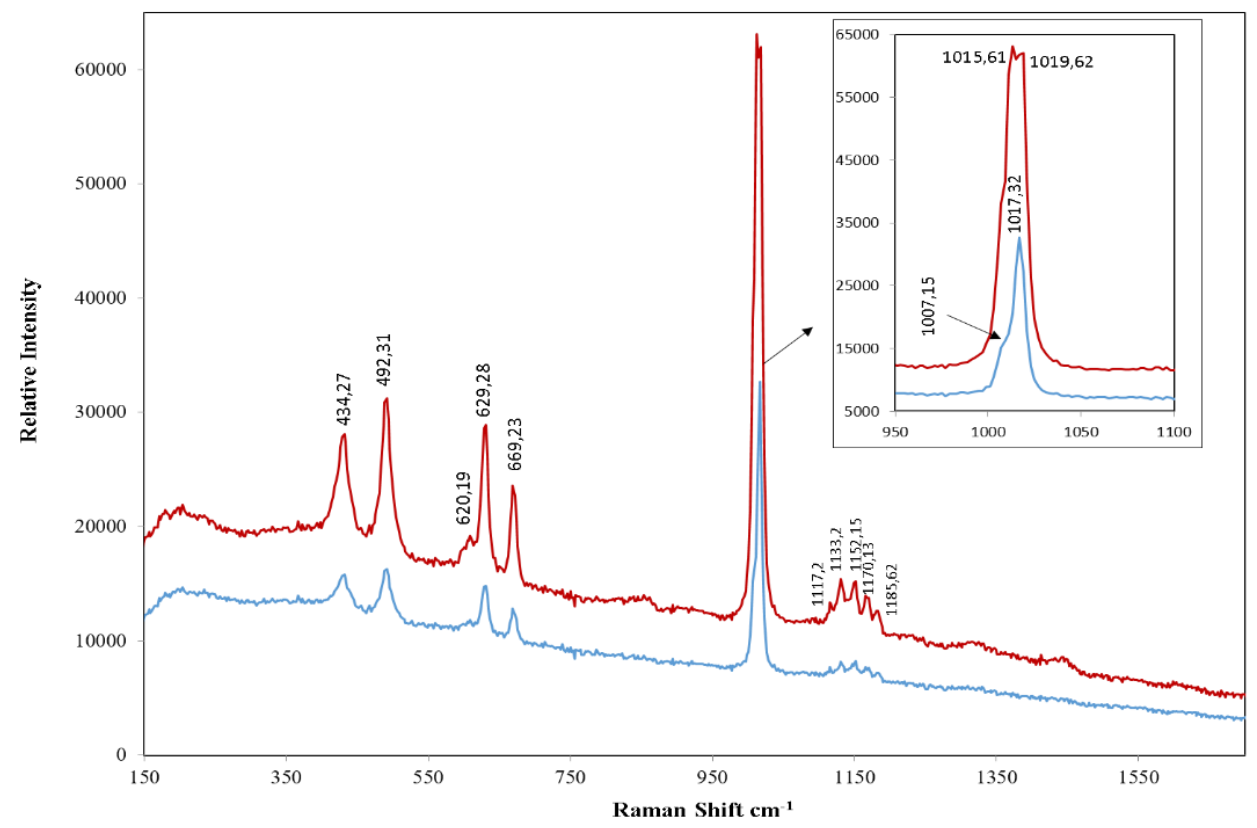

Fig. 4. Raman spectra of the powder 
Unfortunately, the Raman equipment used did not allow us to study the area from $2900 \mathrm{~cm}^{-1}$, which would let to know evolution of water content in the material when it is heated. To study the evolution of water, we performed the analysis FT-IR. Calcium sulphate hemihydrate only contains one type of water molecules, and its characteristic mode of vibration in IR corresponds to a peak at $1617 \mathrm{~cm}^{-1}$, usually accompanied by two less intense and wider peaks at $3600 \mathrm{~cm}^{-1}$ and $3550 \mathrm{~cm}^{-1}$. All these modes of vibration correspond to the water contained in the structure of calcium sulphate [18]. In the FT-IR spectra showed in Figure 5, it is clear the presence of bands positioned at $3549 \mathrm{~cm}^{-1}$ and $3607 \mathrm{~cm}^{-1}$, attributed to the water content of bassanite [16]. Groups of $\mathrm{SO}_{4}{ }^{2-}$ were also identified $\left(593,96 ; 660,48\right.$ and 1005 to $\left.1132 \mathrm{~cm}^{-1}\right)$.

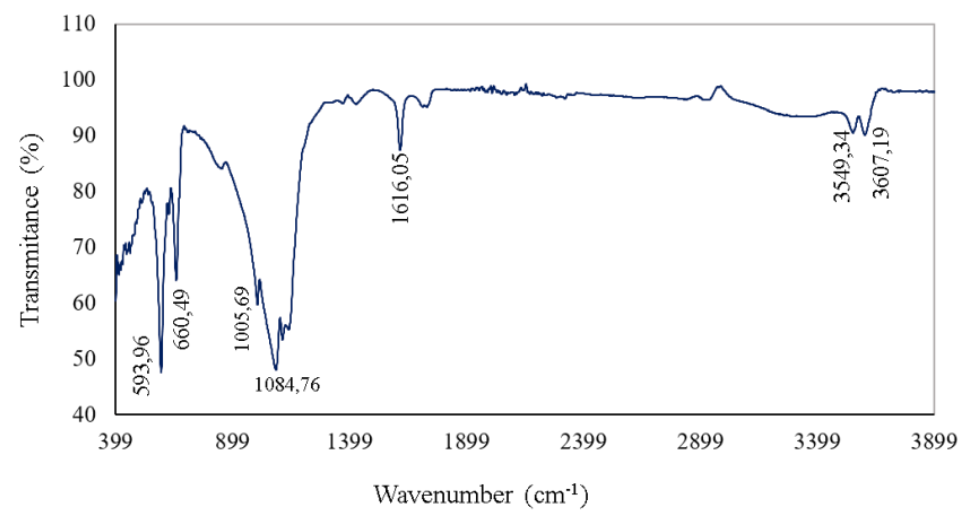

Fig. 5. FT-IR spectra of the powder

The binder used in the 3D printing process to join the powder particles was also analysed. According the safety datesheet provided by 3D System, its chemical composition is 2-pyrrolidone with a purity of $1 \%$. It is necessary to know the exact binder composition for studying the agglomeration process with the raw powder and also to be able to perform adequate thermal post-treatments. For this analysis two techniques were used: ICP-OES and FT-IR. The FT-IR spectra of the binder and pure water appear in Figure 6. The absorption peaks in the region from $1500 \mathrm{~cm}^{-1}$ to $4000 \mathrm{~cm}^{-1}$ are characteristic of pure water. Figure 6 shows the coincidence of water and binder absorption bands in this region. We can conclude that pure water is the majority component on the binder. At lower absorption values $\left(1042,33 \mathrm{~cm}^{-1}\right.$ and $1112,72 \mathrm{~cm}^{-1}$ ) appear peaks which correspond to the 2-pyrrolidone [19].

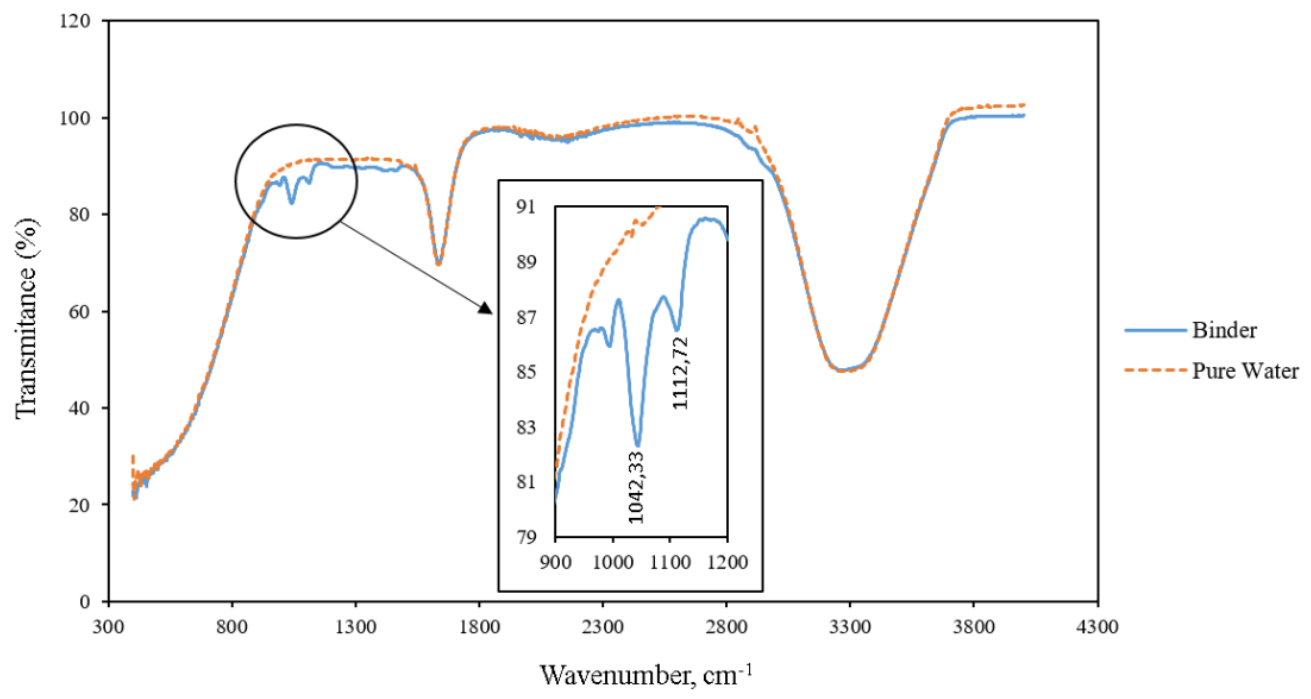

Fig. 6. FT-IR spectra of the binder

Additionally to this study, it was decided to analyse the presence of impurities on the binder. Similarly to the previous study carried out on the powder we used ICP-OES technique. The elements found and their quantity are listed in Table 5. It can be observed the presence of $\mathrm{Na}, \mathrm{K}$ and $\mathrm{Mg}$. All of them are used to improve the setting process, as aforementioned.

\begin{tabular}{|l|c|c|c|c|}
\hline Analite & $\mathrm{Mg}(285,213)$ & $\mathrm{Na}(589,592)$ & $\mathrm{K}(766,490)$ & $\mathrm{Al}(396,153)$ \\
\hline Binder (mg/l) & 0,13 & 73,20 & 2,24 & $<0,10$ \\
\hline
\end{tabular}

Table 5. Chemical composition impurities in the binder 


\section{Conclusions}

Three-dimensional printing process (3DP) highly depends on the used material. Hence, to carry out a in depth study of both powder and binder materials used in 3DP is necessary. Knowledge of composition and properties of materials can improve significantly the 3DP process, allowing extending the use of this technology to new applications. Properties of materials, such as existence of different phases, impurities content, size or shape of crystals affect the printing process and the final part properties. These properties affected are mechanical strength, porosity, surface roughness and postprocessing behaviour. In order to obtain parts which satisfy the requirements for different applications, to know composition and properties of materials used for printing the part is necessary. Therefore, the aim of this study was to characterize one of the most used materials in 3DP technology, hemihydrate calcium sulphate, and the binder, 2 pyrrolidone $1 \%$ of purity. Based on the results discussed in this study, the following remarks can be drawn:

The results of different microscopy and spectroscopy techniques show that the powder exhibits all the species of the system $\mathrm{CaSO}_{4} \bullet \mathrm{H}_{2} \mathrm{O}$. These species are gypsum, hemihydrate and anhydrite, being hemihydrate the main specie. Moreover, it is confirmed that this hemihydrate is a mix between two phases (alpha and beta), being beta the main phase. The alpha and beta phases generate different porous structure, which affect the mechanical properties of the printed parts. The beta phase generates micro cracks and interconnected porous and the alpha phase generates a more homogeneous porosity.

The results obtained with ICP-OES technique showed the exact composition of the materials used in three-dimensional printing (3DP). Both, powder and binder, have impurities such as $\mathrm{Na}, \mathrm{K}$ and $\mathrm{Mg}$, which are added to improve the setting process. Moreover, these impurities can improve the mechanical (resistance to compression) and morphological properties (porosity).

The above information plays a major role in determining the final properties of the 3D printed parts. For example, for applications in which mechanical strength is necessary, a material with more alpha phase content and presence of impurities is required. On the other hand, for applications that require higher porosity in the part, a material with high content of beta phase should be chosen; it is due to alpha phase have crystals with flat faces, so that when joining they imbricate each other giving the whole a great continuity, thus observing a lower porosity than in betha plaster.

Characterization of material is the first step necessary for further development of 3DP specific implementations. Once the composition and properties of the raw materials are known, other studies can be addressed for improving the printing process parameters, the properties of final part or the post-treatment techniques.

\section{Acknowledgments}

Authors thank to Ministry of Science, Innovation and Universities of Spain for the support through the research project with reference DPI2017-89840-R and to the Junta de Castilla y León through the research project with reference FEDER P17-LE027P17.

\section{References}

[1] Ngo, T., Kashani, A., Imbalzano, G., Nguyen, K. T. Q. \& Hui, D. (2018). Additive manufacturing (3D printing): A review of materials, methods, applications and challenges. Composites Part B Engineering, Vol. 143, 2018, pp. 172196, DOI: 10.1016/j.compositesb.2018.02.012.

[2] Peltola, S. M., Melchels, F. P. W., Grijpma, D. W. \& Kellomäki, M. (2008). A review of rapid prototyping techniques for tissue engineering purposes. Annals of Medicine. Vol. 40, $\mathrm{N}^{\mathrm{o}}$ 4, 2008, pp. 268-280, DOI:10.1080/07853890701881788.

[3] Leukers, B., Gülkan, H., Irsen, S.H. et al. (2005). Hydroxyapatite scaffolds for bone tissue engineering made by 3D printing. Journal of Materials Science: Materials in Medicine. Vol. 16, $\mathrm{N}^{\mathrm{o}}$ 12, 2005, pp. 1121-1124, DOI:10.1007/s10856-005-4716-5.

[4] Hwa, L. Ch., Rajoo, S., Noor, A. M., Ahmad, N. \& Uday, M.B. (2017). Recent advances in 3D printing of porous ceramics: A review. Current Opinion in Solid State and Materials Science. Vol. 21, 2017, pp. 323-347, DOI:10.1016/j.cossms.2017.08.002

[5] Lewry, A.J. \& Williamson, J. (1994). The setting of gypsum plaster. Part II. The development of microstructure and strength. Journal of Materials Science. Vol. 29, No 21, 1994, pp. 5524-5528, DOI:10.1007/BF00349943

[6] Farzadi, A., Waran, V., Solati-Hashjin, M., Abdul Rahman, Z. A., Asadi, M. \& Abu Osman, N. A. (2015). Effect of layer printing delay on mechanical properties and dimensional accuracy of 3D printed porous prototypes in bone tissue engineering. Ceramics International, Vol. 41, 2015, pp. 8320-8330, DOI: 10.1016/j.ceramint.2015.03.004.

[7] Zhou, Z., Mitchell, Ch. A., Buchanan, F. J. \& Dunne, N. J. (2013). Effects of heat treatment on the mechanical and degradation properties of 3D-Printed calcium-sulphate-based scaffolds. ISRN Biomaterials, Hindawi Publishing Corporation, Vol. 2013, 10 pages, article ID 750720, DOI: 10.5402/2013/750720

[8] Ledingham, A., English, J., Akyalcin, S., Cozad, B, Ontiveros, J. \& Kasper, F. (2016). Accuracy and mechanical properties of orthodontic models printed 3-dimensionally from calcium sulfate before and after various postprinting treatments. American Journal of Orthodontics and Dentofacial Orthopedics, Vol. 150, Nº 6, 2016, pp. 1056-1062, DOI: 10.1016/j.ajodo.2016.04.027 
[9] Bose, S., Vahabzadeh, S. \& Bandyopadhyay, A. (2013). Bone tissue engineering using 3D printing. Materials Today, Vol. 16, No 12, 2013, pp. 496-504, DOI: 10.1016/j.mattod.2013.11.017

[10] Singh, N.B.\& Middendorf, B. (2007). Calcium sulphate hemihydrate hydration leading to gypsum crystallization. Progress in Crystal Growth and Characterization of Materials. Vol. 53, 2007, pp. 57-77, DOI:10.1016/j.pcrysgrow.2007.01.002.

[11] Zetkova, I; Kucerova, L; Zetek, M; Cesanek, J; Hanzl, P \& Dana, M. (2017). Evaluation of Metal Powder for Additive Manufacturing of Margaring Steel, Proceedings of the 28th DAAAM International Symposium, pp.04100416, B. Katalinic (Ed.), Published by DAAAM International, ISBN 978-3-902734-11-2, ISSN 1726-9679, Vienna, Austria. DOI: 10.2507/28th.daaam.proceedings.057

[12] Rubesova, K; Jenicek, S; Kana, J \& Zetkova, I. (2016). Microstructure of MS1 Maraging Steel in 3D-Printed Products After Semi-Solid Processing, Proceedings of the 27th DAAAM International Symposium, pp.0467-0472, B. Katalinic (Ed.), Published by DAAAM International, ISBN 978-3-902734-08-2, ISSN 1726-9679, Vienna, Austria. DOI: 10.2507/27th.daaam.proceedings.070

[13] Jenicek, S; Bublikova, D; Jirkova, H \& Kana, J (2017). Stability of Retained Austenite in High-Strength Martensitic Steels during Cold Deformation, Proceedings of the $28^{\text {th }}$ DAAAM International Symposium, pp.02890294, B. Katalinic (Ed.), Published by DAAAM International, ISBN 978- 3-902734-11-2, ISSN 1726-9679, Vienna, Austria. DOI: 10.2507/28th.daaam.proceedings.039

[14] Asadi-Eydivand,M., Solati-Hashjin, M., Farzad, A. \& Abu Osman, N. A. (2016). Effect of technical parameters on porous structure and strength of 3D printed calcium sulfate prototypes. Robotics and Computer-Integrated Manufacturing. Vol. 37, 2016, pp.57-67, DOI: 10.1016/j.rcim.2015.06.005

[15] Pattanayak, d. K., Dash, R., Prasad, R.C., Rao, B.T. \& Rama Mohan, T.R. (2007). Synthesis and sintered properties evaluation of calcium phosphate ceramics. Materials Science and Engineering: C, Vol. 27, No. 4, 2007, pp. 684690, DOI: 10.1016/j.msec.2006.06.021

[16] Barbosa, A. A., Ferraz, A. V. \& Santos, G. A. Chemical, mechanical and morphological characterization of gypsum obtained at Araripe, PE, Brazil. Cermica, Vol. 60, 2014, pp. 501-508, ISSN 0366-6913, DOI: 10.1590/S036669132014000400007

[17] Song, K. M., Mitchell, J. \& Gladden, L.F. (2009). Observing Microstructural Evolution During Plaster Hydration. Diffusion-Fundamentals, Vol. 10, 2009, pp. 22.1 - 22.3,

[18] Hamad, S. EI.D. (1981). A study of solid phases in the system $\mathrm{CaSO}_{4}-\mathrm{H}_{2} \mathrm{O}$ : II. Infrared spectra of the hemihydrates and soluble anhydrides, Trans. J. Br. Ceram. Soc, Vol. 80, 1981, pp. 51-55.

[19] http://webbook.nist.gov/cgi/cbook.cgi?ID=C616455\&Mask=80\#IR-Spec. (2017) by the U.S. Secretary of Commerce on behalf of the United States of America. Data compiled by: NIST Mass Spec Data Center, S.E. Stein, director. 